\title{
The Second Advisory Opinion by the Strasbourg Court under Protocol 16:
}

\section{A Contextual Analysis}

Nikos Vogiatzis

Senior Lecturer, School of Law, University of Essex

n.vogiatzis@essex.ac.uk

Advisory Opinion: requested by the Armenian Constitutional Court, Request no. P16-2019001

Section of the Court: Grand Chamber

Applicable Convention Rights: Article 7 ECHR - No punishment without law

Primary Legal issue: "The use of the "blanket reference" or "legislation by reference" technique in the definition of an offence and the standards of comparison between the criminal law in force at the time of the commission of the offence and the amended criminal law'

Link to case: https://hudoc.echr.coe.int/eng\# $\{\% 22$ itemid $\% 22:[\% 22003-6708535-$ $8973165 \% 22]\}$

\section{Introduction}

The reform of the Convention system and the European Court of Human Rights (ECtHR, the Court, the Strasbourg Court) has naturally received significant scholarly attention. ${ }^{1}$ Driven by two possibly competing aims, namely to reduce the workload and to address allegedly activist tendencies of the Strasbourg Court, ${ }^{2}$ the results of the reform agenda remain to be seen. If anything, a significant reduction in the workload has been achieved in quantitative terms ${ }^{3}-$

\footnotetext{
${ }^{1}$ See, among others, L Caflisch, 'The Reform of the European Court of Human Rights: Protocol No. 14 and Beyond' (2006) 6 Human Rights Law Review 403; L Glas, 'From Interlaken to Copenhagen: What Has Become of the Proposals Aiming to Reform the Functioning of the European Court of Human Rights?' (2020) 20 Human Rights Law Review 121.

${ }^{2}$ These tensions notably manifested themselves in the discussions prior to the adoption of Protocol 15 ECHR; see further, N Vogiatzis, "When "Reform" Meets "Judicial Restraint": Protocol 15 Amending the European Convention on Human Rights' (2015) 66 Northern Ireland Legal Quarterly 127.

${ }^{3}$ More than 151,600 allocated applications were pending before the Court by the end of 2011: see, European Court of Human Rights, Annual Report 2011, 13 $<$ https://www.echr.coe.int/Documents/Annual_report_2011_ENG.pdf>; by contrast, at the end of 2018, that figure was around 56,000 applications (see. European Court of Human Rights, Annual Report 2019, $12<$ https://www.echr.coe.int/Documents/Annual_report_2019_ENG.pdf>).
} 
although the situation with the existing pending applications is suboptimal, and the grounds on which such reduction has been achieved are not entirely clear or necessarily wholly attributable to amendments introduced by Protocol $14 .{ }^{4}$ Despite this, the criticism against the Court does not appear to have eased. Although voices from within Strasbourg, particularly over recent years, have sought to emphasise the significance of subsidiarity, ${ }^{5}$ states sceptical of European supervision continue to challenge the Court's authority and legitimacy. ${ }^{6}$ At the time of writing, Protocol 15, inserting the notions of subsidiarity and margin of appreciation into the preamble to the European Convention on Human Rights (ECHR, the Convention), has not yet entered into force, but it is reasonable to suggest that this date is fast approaching. It will be particularly interesting to see the impact of this protocol on the interpretation of the Convention by the Court. $^{7}$

Simultaneously, Protocol 16 ECHR entered into force in August 2018 with respect to the ten states - at that time -that had ratified it. The number of ratifications has now risen to $15 .^{8}$ Protocol 16 strengthens, or expands, the advisory jurisdiction of the Strasbourg Court. Article 1(1) of that Protocol provides as follows:

Highest courts and tribunals of a High Contracting Party, as specified in accordance with Article 10, may request the Court to give Advisory Opinions on questions of principle relating to the interpretation or application of the rights and freedoms defined in the Convention or the protocols thereto.

\footnotetext{
${ }^{4}$ An area where further research is clearly needed is the Court's use of the 'manifestly ill-founded' admissibility criterion under Article 35(3)(a) ECHR. For some critical observations in this respect, see, H Keller et al, 'Debating the Future of the European Court of Human Rights after the Interlaken Conference: Two Innovative Proposals' (2010) 21 European Journal of International Law 1025.

${ }^{5}$ See, for example, a piece which has proved rather influential by the current President of the ECtHR: R Spano, 'Universality or Diversity of Human Rights? Strasbourg in the Age of Subsidiarity' (2014) 14 Human Rights Law Review 487. This is not the place, of course, to offer a comprehensive examination or assessment of novel conceptions of subsidiarity in the case law of the Strasbourg Court.

${ }^{6}$ The episodes prior to the Copenhagen Declaration are indicative of such scepticism. However, the draft declaration was criticised by, among others, A Donald and P Leach, 'A Wolf in Sheep's Clothing: Why the Draft Copenhagen Declaration Must be Rewritten' (EJIL:Talk!, 21 February 2018): <https://www.ejiltalk.org/a-wolfin-sheeps-clothing-why-the-draft-copenhagen-declaration-must-be-rewritten>; A Follesdal and G Ulfstein, 'The Draft Copenhagen Declaration: Whose Responsibility and Dialogue?' (EJIL: Talk!, 22 February 2018): $<$ www.ejiltalk.org/the-draft-copenhagen-declaration-whose-responsibility-and-dialogue $>$.

${ }^{7}$ Reflections on how Protocol 15 may be interpreted by the Strasbourg Court are offered in Vogiatzis (n 2).

${ }^{8}$ For a table of signatures and ratifications of Protocol 16, see, <www.coe.int/en/web/conventions/full-list//conventions/treaty/214/signatures?p_auth $=\mathrm{v} 4 \mathrm{tClnIP}>$.
} 
To date, the ECtHR has delivered two Opinions under that Protocol. The first Opinion was delivered in 2019 at the request of the French Court of Cassation ${ }^{9}$ (and is returned to in later sections of this note). The second Advisory Opinion, which is the focus of the present contribution, was delivered in May 2020 at the request of the Armenian Constitutional Court. ${ }^{10}$

Whereas this note will comment on the substance of the second Opinion, its key purpose is to provide some (preliminary) observations about Protocol 16 through the 'lens' of that Opinion, whilst also taking into account the first Opinion of 2019. With the necessary disclaimer that it is rather early to provide categorical conclusions about Protocol 16 and its possible impact on the Convention system, this note assesses favourably the practice of the Strasbourg Court to date. It is argued that the ECtHR has so far plausibly interpreted its jurisdictional remit under Article 1 of Protocol 16, even if this has had the consequence of refraining from providing an answer to certain broadly framed questions; the power to reformulate questions has been used in order to assist the national courts; and, crucially, Protocol 16 should be viewed as a form of dialogue between Strasbourg and its national interlocutors. As such, the responsibility for the success or otherwise of the scheme also rests with domestic courts and cannot solely be attributed to Strasbourg.

\section{Protocol 16 ECHR: What It Is and What It Is Not}

As already noted, Article 1 of Protocol 16 outlines the Advisory jurisdiction of the Court. In such Article it is specified that the opinion - which is optional for high-ranking courts and tribunals - shall be requested 'only in the context of a case pending' before the court or tribunal, and that the latter 'shall give reasons for its request and shall provide the relevant legal and factual background of the pending case'. Article 2 of the Protocol specifies that if the request is accepted, the opinion will be delivered by the Grand Chamber; dissenting or concurring opinions are possible (Article 4(2)), and the Advisory Opinion is not legally binding (Article 5 of the Protocol).

The background to the Protocol is illustrated in the Explanatory Report. In brief, the key aim was to strengthen dialogue between national courts and the ECtHR and to 'enhance the Court's

\footnotetext{
${ }^{9}$ Advisory Opinion Concerning the Recognition in Domestic Law of a Legal Parent-Child Relationship between a Child Born through a Gestational Surrogacy Arrangement Abroad and the Intended Mother, Request no. P162018-001 (ECtHR, 10 April 2019).

${ }^{10}$ Advisory Opinion Concerning the use of the "Blanket Reference" or "Legislation by Reference" Technique in the Definition of an Offence and the Standards of Comparison between the Criminal Law in Force at the Time of the Commission of the Offence and the Amended Criminal Law, Request no. P16-2019-001 (ECtHR, 29 May 2020).
} 
"constitutional" role', in the context of the long-term effectiveness of the ECHR system. ${ }^{11}$ The Report also elaborates on the nature of the questions that may be posed by the national court, as well as the necessary requirement that a pending case should precede the request. These matters are returned to below. The Strasbourg Court has also adopted non-binding guidelines to assist the competent national courts and tribunals in their submissions, and to enhance the clarity of the mechanism more generally. ${ }^{12}$ Among others, the Court recommends that the Opinion may be submitted 'only after, in so far as relevant, the facts and legal issues, including issues of Convention law, have been identified'. ${ }^{13}$ In light of the aims of Protocol 16, the Court intends to provide 'clear interpretative guidance' - hence the requirements for the domestic courts to provide reasons and a number of elements. ${ }^{14}$ The domestic court, upon the receipt of the non-binding opinion 'is invited to inform the Court of the follow-up given to the Advisory Opinion in the domestic proceedings'. ${ }^{15}$

In addition, the Rules of Court were updated in 2017 to cater for the forthcoming entry into force of Protocol 16. It is specified therein and inter alia that a panel of five judges will initially examine the request, and such requests 'shall be processed as a matter of priority in accordance with Rule 41'.16

As the above discussion demonstrates, Protocol 16 is a form of dialogue introduced by the Convention, which strengthens the 'constitutionalist' function of the Court. ${ }^{17}$ As with any form

${ }^{11}$ Council of Europe, Explanatory Report to Protocol No. 16 to the Convention for the Protection of Human Rights and Fundamental Freedoms, paras 1-6.

12 European Court of Human Rights, 'Guidelines on the Implementation of the Advisory-Opinion Procedure Introduced by Protocol No. 16 to the Convention' (2017): < https://www.echr.coe.int/Documents/Guidelines_P16_ENG.pdf $>$.

${ }^{13}$ Ibid para 10.

${ }^{14}$ Ibid para 11 (emphasis added). These elements are outlined at para 12 and Rule 92 of the Rules of Court, and beyond the questions on which guidance is sought the following should also be included:

'(a) the subject matter of the domestic case and its relevant legal and factual background;

(b) the relevant domestic legal provisions;

(c) the relevant Convention issues, in particular the rights or freedoms at stake;

(d) if relevant, a summary of the arguments of the parties to the domestic proceedings on the question;

(e) if possible and appropriate, a statement of the requesting court or tribunal's own views on the question, including any analysis it may itself have made of the question.'

${ }^{15}$ Ibid para 31 (emphasis added).

16 European Court of Human Rights, Rules of Court (2020): $<$ https://www.echr.coe.int/documents/rules_court_eng.pdf $>$ Rule 93. Rule 41 states, among others, that '[i]n determining the order in which cases are to be dealt with, the Court shall have regard to the importance and urgency of the issues raised on the basis of criteria fixed by it'.

17 On this debate see, among others, F de Londras, 'Dual Functionality and the Persistent Frailty of the European Court of Human Rights' (2013) European Human Rights Law Review 38; K Dzehtsiarou and A Greene, 'Restructuring the European Court of Human Rights: Preserving the Right of Individual Petition and Promoting Constitutionalism' (2013) Public Law 710; S Greer and L Wildhaber, 'Revisiting the Debate about “Constitutionalising” the European Court of Human Rights' (2012) 12 Human Rights Law Review 655; N 
of dialogue, in order to be successful engagement from both parties (in this case, the other party is an eligible high-ranking court of one of the contracting parties which has ratified the Protocol ${ }^{18}$ ) is required. Protocol 16 cannot, in and of itself, reduce the workload of the Court. ${ }^{19}$ Moreover, it is not a mechanism via which the Court will provide interpretations to abstract legal questions that may arise in the future. It also shares a number of similarities (as well as some differences) with the preliminary reference procedure under European Union law. ${ }^{20}$ All of the above points are returned to below.

\section{The Second Advisory Opinion by the ECtHR: The Answers on the Interpretation of Article 7 ECHR}

The Advisory Opinion was requested on 2 August 2019, and the Court delivered its Opinion on 29 May 2020. In 2018, the former President of Armenia, Robert Kocharyan, and a number of other individuals were charged "with overthrowing the constitutional order of Armenia under Article $300.1 \S 1$ of the 2009 Criminal Code'. ${ }^{21}$ The charges were related to demonstrations that took place in 2008, after an election that was not deemed free and fair by the demonstrators; the standoff resulted in ten deaths, a declaration of a state of emergency by Kocharyan, and the restriction of a number of rights, including freedom of assembly, for twenty days. ${ }^{22}$

As already noted, the charges were initiated under the 2009 Criminal Code and not under Article 300 of the Criminal Code in force at the material time, titled 'usurpation of power'. It appears from the Opinion, and the discussion of the domestic legal framework therein, that a specific criminal offence of overthrowing the constitutional order was added under the 2009 Code, whilst in 2008 such offence was punishable under the 'usurpation of power' provision. ${ }^{23}$

In this context, Article 7 ECHR (no punishment without law) was the provision that prompted the request to Strasbourg. ${ }^{24}$ Four questions were submitted to the Strasbourg Court, which felt

\footnotetext{
Vogiatzis, "The Admissibility Criterion under Article 35(3)(b) ECHR: A "Significant Disadvantage" to Human Rights Protection?' (2016) 65 International and Comparative Law Quarterly 185.

18 See, Guidelines (n 12) Appendix II, containing a list of the courts or tribunals designated by the High Contracting Parties pursuant to Article 10 of Protocol 16.

${ }^{19}$ See, K Dzehtsiarou and N O'Meara, 'Advisory Jurisdiction and the European Court of Human Rights: A Magic Bullet for Dialogue and Docket-Control?’ (2014) 34 Legal Studies 444.

${ }^{20}$ See, Article 267 of the Treaty on the Functioning of the European Union (TFEU).

${ }^{21}$ Advisory Opinion P16-2019-001 (n 10) para 16.

${ }^{22}$ Ibid para 14.

${ }^{23}$ Ibid paras 24-26.

${ }^{24}$ Article 7(1) ECHR provides: 'No one shall be held guilty of any criminal offence on account of any act or omission which did not constitute a criminal offence under national or international law at the time when it was committed. Nor shall a heavier penalty be imposed than the one that was applicable at the time the criminal offence was committed'.
} 
unable to answer the first and second of these on the basis of its jurisdiction under Protocol 16; thus, only the third and fourth questions were answered. The issue of refusing to answer the first two questions will be examined in the following section. Here, the focus is on the third and fourth questions, which were answered.

As the title of the Opinion also indicates, central in the case were the notions of "blanket reference" or "legislation by reference" technique in the definition of an offence. The Court undertook a comparative exercise across forty-one states of the Council of Europe, while defining these terms as follows: 'the legislative technique where substantive provisions of criminal law, when setting out the constituent elements of criminal offences, refer to legal provisions outside criminal law'. ${ }^{25}$ All except two states relied on this technique, while twentyone states did so regarding criminal offences against the constitutional order of their country. ${ }^{26}$

This finding informed the Court's analysis and answer to the third question submitted by the Armenian Constitutional Court, ${ }^{27}$ namely that defining the above crime using this technique is not against the requirements of legal certainty and foreseeability under Article 7 ECHR. The Court also took into consideration case law which, although falling short from providing an explicit statement about this technique, nevertheless indicated the implied acceptance of it by the Strasbourg Court with respect to the criminal law of several member states. ${ }^{28}$ The Court added, however, that the use of the technique should still not undermine 'general "quality of law" requirements': the law 'must be sufficiently precise, accessible and foreseeable in its application'. ${ }^{29}$ Even when this technique is being used by states, 'both norms (the referencing and the referenced provision) taken together must enable the persons concerned to foresee, if need be with the help of appropriate legal advice, what conduct may make them criminally liable'. ${ }^{30}$

\footnotetext{
${ }^{25}$ Ibid para 31.

${ }^{26}$ Ibid para 32.

${ }^{27}$ The third question was worded as follows: 'Does the criminal law that defines a crime and contains a reference to certain legal provisions of a legal act with supreme legal force and higher level of abstraction meet the requirements of certainty, accessibility, foreseeability and stability?'

${ }^{28}$ See, among others, the following judgments (all cited in the Advisory Opinion): Del Río Prada v Spain 42750/09 (ECtHR, 21 October 2013); Vasiliaouskas v Lithuania [GC] 35343/05 (ECtHR, 20 October 2015); Haarde v Iceland 66847/12 (ECtHR, 23 November 2017); Kuolelis and Others v Lithuania 74357/01 (ECtHR, 19 February 2008).

${ }^{29}$ Advisory Opinion P16-2019-001 (n 10), para 72.

${ }^{30}$ Ibid. It was also added at para 73 that: 'the Court considers that the most effective way of ensuring clarity and foreseeability is for the reference to be explicit, and for the referencing provision to set out the constituent elements of the offence. Moreover, the referenced provisions may not extend the scope of criminalisation as set out by the referencing provision. In any event, it is up to the court applying both the referencing provision and the referenced provision to assess whether criminal liability was foreseeable in the circumstances of the case.'
} 
The fourth question sought guidance by the ECtHR as to the principles that should be applied in order to compare the criminal law in force at the time when the act or acts were committed, and the amended criminal law, on the basis of which charges were initiated. ${ }^{31}$ This is a pertinent question in light of the principle of non-retroactivity of criminal law under Article 7 ECHR, which entails, among others, the prohibition of retrospectively applying criminal law when doing so is to the disadvantage of the accused person. ${ }^{32}$ The answer of the Strasbourg Court pointed to the principle of concretisation, taking also into account the comparative material (indicating that more than half of states also rely on it) and its own case law. ${ }^{33}$ The principle means that 'it is necessary to determine in concreto which law is more favourable to the accused and then to apply that law'. ${ }^{34}$ The matter becomes slightly more complex, however, when the penalty under the newer criminal law does not differ, but the offence is nevertheless reclassified. Even in such cases, the Court emphasised in the Opinion that the comparison should 'be carried out by the competent court, not by comparing the definitions of the offence in abstracto, but having regard to the specific circumstances of the case' ${ }^{35}$ In essence, the ECtHR extended the application of the principle of concretisation to instances where there is no apparent issue of a more lenient penalty, which nonetheless involve 'a comparison between the definition of the offence at the time of its commission and a subsequent amendment'. ${ }^{36}$ Such was the case here, with the additional challenge that the new definition was broader in one respect and narrower in another. It was then left to the national court to draw inferences from this guidance and correctly apply the principles under Article 7 ECHR.

The answers by the Court sought to emphasise the significance of Article 7, a non-derogable right, ${ }^{37}$ for the rule of law, whilst also being mindful of the inevitable divergences of the criminal justice systems across the contracting parties. In doing so, the ECtHR appears to have succeeded in providing useful guidance to the requesting Court whilst respecting its subsidiary

\footnotetext{
${ }^{31}$ It was worded as follows: 'In the light of the principle of non-retroactivity of criminal law (Article $7 \S 1$ of the Convention), what standards are established for comparing the criminal law in force at the time of committal of the crime and the amended criminal law, in order to identify their contextual (essential) similarities or differences?'.

${ }^{32}$ As the Opinion explained (para 81), the principle of the retrospective application of the more lenient criminal law is also pertinent, established by the Court in Scoppola v Italy (No 2) [GC] 10249/03 (ECtHR, 17 September 2009). Accordingly, the Court of Justice of the European Union in Berlusconi and Others found that the 'principle of the retroactive application of the more lenient penalty forms part of the constitutional traditions common to the Member States'; see, Berlusconi and Others, Joined Cases C-387/02, C-391/02 and C-403/02, EU:C:2005:270 (CJEU, 3 May 2005) para 68.

${ }^{33}$ Advisory Opinion P16-2019-001 (n 10) para 79.

${ }^{34}$ Ibid para 38.

${ }^{35}$ Ibid para 88 .

${ }^{36}$ Ibid para 90.

${ }^{37}$ See, Article 15 ECHR.
} 
role which means, among others, that in principle it should not be the Court itself addressing errors of fact or law. This balance inevitably requires a degree of abstraction. It will be interesting to see how the Court will navigate this challenge in the new institutional landscape offered by Protocol 16.

If anything, it is submitted that the first Advisory Opinion (which cannot be discussed at length in this contribution ${ }^{38}$ ) confirms this position. Therein, the Court was called upon to assess whether 'Article 8 of the Convention requires domestic law to provide a possibility of recognition of the relationship between a child born through a gestational surrogacy arrangement abroad and the intended mother'. ${ }^{39}$ In finding in the affirmative, the Strasbourg Court placed particular emphasis on the best interests of the child. ${ }^{40}$ Accordingly, states' margin of appreciation should be reduced - particularly in circumstances of 'general and absolute impossibility of obtaining recognition'. ${ }^{41}$ Noteworthily, the Court found so regardless of the absence on European consensus on this matter. ${ }^{42}$ This can hardly be criticised: the better view on the interplay between consensus and the margin of appreciation is that the former may often, but not always, inform the Court's approach as to the latter. ${ }^{43}$ Nonetheless, the means by which such recognition should take place was to a certain extent left to states (France, in this case), provided that 'an effective mechanism should exist enabling that relationship to be recognised'. ${ }^{44}$ As Buyse observed, what one makes of the first Opinion depends on how one sees the mechanism under Protocol 16 (and that Opinion 'certainly [did] not solve all issues related to gestational surrogacy, ${ }^{45}$ ). Accordingly, Margaria observed that 'by reading Article 8 as implying the possibility for recognition, but not of a specific type ... the Court manages to advance the interpretation of the Convention as a "living instrument" whilst respecting (some) national variations'. ${ }^{46}$ Such discussion is revisited in subsequent sections of this note.

\section{The ECtHR's Jurisdiction under Article 1 of Protocol 16 ECHR}

\footnotetext{
${ }^{38}$ See, A Buyse, 'Analysis: The Strasbourg Court's First Advisory Opinion under Protocol 16' (ECHR Blog, 10 May 2019) <echrblog.blogspot.com/2019/05/the-european-courts-first-advisory.html>.

${ }^{39}$ Advisory Opinion P16-2018-001 (n 9) para 37.

${ }^{40}$ Ibid paras $40-42$.

${ }^{41}$ Ibid paras 42 and 43-47.

${ }^{42}$ Ibid para 43.

${ }^{43}$ See, $N$ Vogiatzis, 'The Relationship Between European Consensus, the Margin of Appreciation and the Legitimacy of the Strasbourg Court' (2019) 25 European Public Law 445.

${ }^{44}$ Advisory Opinion P16-2018-001 (n 9), para 54.

${ }^{45}$ Buyse (n 38).

${ }^{46}$ A Margaria, 'Parenthood and Cross-Border Surrogacy: What Is "New"? The ECtHR's First Advisory Opinion' (2020) 28 Medical Law Review 412, 425.
} 
The first and second questions ${ }^{47}$ posed by the Armenian Constitutional Court were not answered by the Strasbourg Court, which, mindful of its jurisdictional limits under Article 1 of Protocol 16, decided that they were rather broad and unrelated to the facts of the case. In particular, the second paragraph of the abovementioned Article states that request should be submitted 'only in the context of a case pending before it'. The Court had already established from its first Advisory Opinion that the purpose of the mechanism under Protocol 16 is 'not to transfer the dispute to the Court, but rather to give the requesting court guidance on Convention issues when determining the case before it' ${ }^{48}$

In the above sense, it is immediately apparent that the mechanism under Protocol 16 serves a different purpose of subsidiarity: a subsidiarity which entails, first and foremost, a form of dialogue between Strasbourg and the national interlocutor that should assist the latter to make an informed decision. The ECtHR is not called upon to resolve the dispute as a court of last resort. ${ }^{49}$ Thus, the Protocol 'places the interpreters of the Convention in a complementary, rather than competitive, relationship'. ${ }^{50}$ This was also underlined in the first Opinion, where the Court, considering the extent to which it would engage with written observations ${ }^{51}$ of the participants in the proceedings, stressed that:

its task is not to reply to all the grounds and arguments submitted to it or to set out in detail the basis for its reply; under Protocol No. 16, the Court's role is not to rule in adversarial proceedings on contentious applications by means of a binding judgment but rather, within as short a time frame as possible, to provide the requesting court or tribunal with guidance enabling it to ensure respect for Convention rights when determining the case before it. ${ }^{52}$

\footnotetext{
${ }^{47}$ These questions were worded as follows: "1) Does the concept of "law" under Article 7 of the Convention and referred to in other Articles of the Convention, for instance, in Articles 8-11, have the same degree of qualitative requirements (certainty, accessibility, foreseeability and stability)?' '2) If not, what are the standards of delineation?'.

${ }^{48}$ Advisory Opinion P16-2018-001 (n 9) para 25.

${ }^{49}$ And, indeed, it is possible that the matter on which the Strasbourg Court has already provided an Opinion under Protocol 16 could still be the subject of an application to the ECtHR if the applicant is unsatisfied with the domestic court's interpretation of the Strasbourg guidance: see, K Lemmens, 'Protocol No 16 to the ECHR: Managing Backlog Through Complex Judicial Dialogue?’ (2019) 15 European Constitutional Law Review 691, 703.

${ }^{50}$ C Giannopoulos, 'Considerations on Protocol N 016: Can the New Advisory Competence of the European Court of Human Rights Breathe New Life into the European Convention on Human Rights?' (2015) 16 German Law Journal 337, 342.

${ }^{51}$ It is noted, in this respect, that Article 3 of Protocol 16 provides that the Council of Europe Commissioner for Human Rights and the contracting party concerned have the right to submit written comments and participate in the hearing, but the President of the Court may, 'in the interest of the proper administration of justice invite any other High Contracting Party or person also to submit written comments or take part in any hearing.'

${ }^{52}$ Advisory Opinion P16-2018-001 (n 9) para 34.
} 
In the second Opinion the novel issue was whether the Court could answer some, but not all, of the questions submitted by the domestic Court (its competence to reformulate the questions is addressed in the next section of this note). Procedurally this is interesting because a panel of five judges, under Article 2 of Protocol 16, decide whether or not the request will be accepted, but once this is decided the question(s) is/are then examined by the Grand Chamber, which provides the Opinion. The Court answered this in the affirmative, being mindful of its jurisdiction under the Convention. ${ }^{53}$

The ECtHR also underlined that the stage in the domestic proceedings at which the request will be submitted may also inform its approach to accepting (or not) certain questions. Thus, the second request was contrasted with the first one, in which the factual framework had been judicially assessed and the link to the legal questions was available to the Strasbourg Court. ${ }^{54}$ In light of these considerations, the Strasbourg Court felt that the first question (and, consequently, also the second one because it was connected to the first) did not meet the jurisdictional requirements under Article 1 of Protocol 16. In particular, it '[did] not discern any direct link between the first and second questions and the pending domestic proceedings'. ${ }^{55}$ It was, moreover, unclear to the Court (on the basis of the file that had been received) on which basis Articles 8-11 ECHR were invoked by the domestic court. ${ }^{56}$

At this point, it is appropriate to also consider the practice of the Court of Justice of the European Union when receiving preliminary questions. ${ }^{57}$ To be sure, the preliminary reference procedure has similarities, but also important differences, which have been the subject of scholarly analysis. ${ }^{58}$ To name but a few differences, a preliminary reference is binding on the national court, the latter can also submit questions on the validity of EU acts, and a national

\footnotetext{
${ }^{53}$ Articles 19, 32 and (by analogy) 48 ECHR were referenced (Advisory Opinion P16-2019-001 (n 10) para 47). The Court's advisory jurisdiction under Articles 47-49 ECHR is returned to below.

${ }^{54}$ Advisory Opinion P16-2019-001 (n 10) para 49.

${ }^{55}$ Ibid para 53.

${ }^{56}$ As the Court pointed out, 'there is nothing in the factual context of the case that could be perceived as the exercise of [Mr Kocharyan's] rights under Articles 8-11 of the Convention' (para 54); in addition, regarding 'the legal context of the domestic proceedings, the Court finds it difficult to see which questions the Constitutional Court wishes to determine with the help of the Court's opinion' (para 55), while adding that questions of legal certainty and foreseeability could sufficiently be addressed by the Court's answer to the third question.

${ }^{57}$ For a thorough study, see, M Broberg and N Fenger, Preliminary References to the European Court of Justice (Oxford University Press 2014).

${ }^{58}$ See, among others, J Gerards, 'Advisory Opinions, Preliminary Rulings and the New Protocol No. 16 to the European Convention of Human Rights: A Comparative and Critical Appraisal' (2014) 21 Maastricht Journal of European and Comparative Law 630; P Gragl, '(Judicial) Love is not a One-Way Street: the EU Preliminary Reference Procedure as a Model for ECtHR Advisory Opinions under Draft Protocol No.16' (2013) 38 European Law Review 229; S O'Leary and T Eicke, 'Some Reflections on Protocol No.16' (2018) European Human Rights Law Review 220.
} 
court of last resort is obliged to refer to the CJEU if it has doubts regarding questions of interpretation - among others. By contrast, the Advisory opinion under Protocol 16 is nonbinding; there is obviously no competence conferred on the Strasbourg Court to rule on the validity of an act (with the disclaimer that the ECHR is an entirely different system which does not have all the legal characteristics of the EU legal order); and the referral to Strasbourg is optional under all circumstances. This is not an exhaustive comparison (insightful studies already exist, as noted above) and similarities between the two mechanisms also exist. However, the point to be made here is that it is almost impossible for the Strasbourg Court not to have drawn at least some inspiration from the practice of the Luxembourg Court with regard to preliminary rulings. ${ }^{59}$ For example, the guidance that the Strasbourg Court has produced which is also duplicated in the Rules of Court - presents similarities to the one drafted by the Luxembourg Court in order to help the domestic referring courts to provide as much information as possible. ${ }^{60}$

In this context, it is indeed the case that the Luxembourg Court has established that purely hypothetical or abstract cases cannot be answered via a preliminary reference. ${ }^{61}$ As Gragl observed, the preliminary reference influenced the drafters of Protocol 16 on this point. Defending this approach, Gragl argued that answers to abstract or hypothetical questions, beyond resource implications, would also 'prove detrimental to the coherence of the Court's case law if an abstract or hypothetical legal issue becomes "concrete", but not in the same manner as envisaged in the Court's judgment', thereby producing legal uncertainty and possibly 'contradicting decisions'. ${ }^{62}$

It is submitted that the lack of engagement with the first two questions is defensible and clearly stems from the Court's own understanding of the nature of Protocol 16 as manifested in the first Advisory Opinion; but it also accords with the Explanatory report to the Protocol and the

\footnotetext{
${ }^{59}$ As readers of this Review will no doubt be aware, the Luxembourg Court has not been exactly enthusiastic to the prospects of Protocol 16 entering into force, seen in light of the (currently uncertain) EU accession to the ECHR; see, Opinion 2/13 on the Draft Agreement Providing for the Accession of the European Union to the Convention for the Protection of Human Rights and Fundamental Freedoms, EU:C:2014:2454 (CJEU, 18 December 2014) paras 196-199.

${ }^{60}$ See, Recommendations to National Courts and Tribunals in Relation to the Initiation of Preliminary Rulings Proceedings, 2019/C 380/01 (CJEU, 8 November 2019).

${ }^{61}$ See, for example, Wightman, Case C-621/18, EU:C:2018:999 (CJEU, 10 December 2018) para 27: 'The Court may refuse to rule on a question referred for a preliminary ruling by a national court only where it is quite obvious that the interpretation of EU law that is sought bears no relation to the actual facts of the main action or its purpose, where the problem is hypothetical, or where the Court does not have before it the factual or legal material necessary to give a useful answer to the questions submitted to it' (and case law cited therein). As is known, of course, in Wightman it concluded that the question was admissible.

${ }^{62}$ Gragl (n 58) 237-238.
} 
idea that Protocol 16 should establish a dialogue that would be of assistance to the domestic court in the context of the particular case before it. It furthermore accords with the approach taken by the CJEU - although, obviously a sample of two cases in approximately two years of operation cannot provide any definitive conclusions on how the ECtHR understands its jurisdiction (and the limits thereof) under Protocol 16.

Nonetheless, it might be useful to pose the question as to what precisely would have been gained had the Court answered the first and second more abstract questions. To be sure, this author does not 'read' any severe criticism from the Strasbourg Court to the Armenian Court in the Opinion, not least since the guidance to Article 7 in questions three and four should, in principle, be useful (although the ECtHR did say, for example, in its preliminary considerations that 'the questions submitted by the Constitutional Court are, at least in part, broad and very general $^{93}$ - a formulation which, seen in the spirit of dialogue established under a novel mechanism, could have been avoided). Yet, leaving aside how the ECtHR could have formulated its preliminary considerations, there is little doubt that the Armenian Constitutional Court posed an interesting question from a scholarly point of view, yet one that was not apparently related to the factual and legal framework. Had the Court engaged in a more abstract answer, in this respect, there would be a risk of undermining legal certainty and ultimately providing a confusing answer to the Constitutional Court, which appears to contradict the aims of Protocol 16. Thus, refusing to answer these questions cannot be deemed to undermine, in this case at least, 'judicial comity'. ${ }^{64}$

In that sense, the lack of engagement with this question could also serve as a message to national courts to submit questions that certainly concern the interpretation of the Convention, but would be helpful, nonetheless, in the adjudication of the precise legal and factual framework before them. Could this discourage national courts from putting questions forward?

\footnotetext{
${ }^{63}$ Advisory Opinion P16-2019-001 (n 10), para 41.

64 'Judicial comity' is a term that has various meanings (see, for example, E D'Alteiro, 'From Judicial Comity to Legal Comity: A Judicial Solution to Global Disorder?' (2011) 9 International Journal of Constitutional Law 394), including 'respect for the judgments of foreign courts', in the sense that a judge may follow the judgment of an equal jurisdiction 'as a matter of judicial comity', even if they are not obliged to do so (M Amos, 'The Principle of Comity and the Relationship between British Courts and the European Court of Human Rights' (2009) 28 Yearbook of European Law 503, 505). In the context of Protocol 16 ECHR, the notion (or lack thereof) has been used to denote reluctance, on the part of the Court, to answer questions due to possible workload implications or 'insensitivities' when reformulating questions (Dzehtsiarou and O'Meara (n 19) 466). As noted earlier, in this case at least the Court did not answer the questions on the basis of a (plausible) reading of its jurisdiction, rather than concerns regarding its workload.
} 
It is rather early to know, of course, but it is here that the power of the Court to reformulate questions, insofar as this is possible, comes into play. This is discussed in the next section.

\section{The ECtHR's Power to Reformulate Questions}

The power of the Strasbourg Court to reformulate questions should not be underestimated - if anything, it might be a way to 'save' the 'acceptance' of the request, as already noted. This power is the ECtHR's own creation and, once again, the possible influence of the Luxembourg Court cannot be excluded. Insightful studies explore how the CJEU reformulates questions: not only to maximise precision and the usefulness of the answer, but also to respect the jurisdictional boundaries between the national and the EU judiciary. ${ }^{65}$ Thus, the question may be narrowed-down, other provisions of EU law may be included, questions might be merged among others. 66

Turning now to the ECtHR, Dzehtsiarou and O'Meara observed that the power to reformulate questions was mentioned in the draft Explanatory report but omitted in the published version. ${ }^{67}$ Yet, it seems that for the Court it has always been clear that such power exists under a combined reading of Articles 1(1) and 2 of Protocol 16. ${ }^{68}$ Indeed, the Court did so with regard to both Opinions delivered so far. To focus on the second Opinion, the third and fourth questions were reformulated to improve clarity and precision (see above).

In this context, such power of the Strasbourg Court can work to the benefit of the domestic court requesting an Opinion; in light of decades of experience, not only might the Strasbourg Court be in a position to reformulate a question in a 'Convention-relevant' manner, so to speak, but also via this technique the risk of refusal to provide an answer is minimised. That being said, the second Opinion certainly indicates that the reformulation technique (as was shown with the first two questions) has limits: the Strasbourg Court may not consider rather abstract questions via reformulation. The power to reformulate questions cannot go against the jurisdiction of the Court under Article 1 of Protocol 16, but only operate within the limits of that provision.

\section{The ECtHR's Practice and Technique in Answering the Submitted Questions}

\footnotetext{
${ }^{65}$ Broberg and Fenger (n 57) 412-414.

${ }^{66}$ Ibid 415-435.

${ }^{67}$ Dzehtsiarou and O’Meara (n 19) 466.

${ }^{68}$ Advisory Opinion P16-2019-001 (n 10) paras 44-45.
} 
There is an understandable risk that an Opinion under Protocol 16 could extend the domestic proceedings even further ${ }^{69}$ - if anything, several states across the Council of Europe cannot exactly claim a paucity of violations concerning the length of judicial proceedings (and therefore a violation of the requirement to have a fair and public hearing within a reasonable time) under Article 6 ECHR. ${ }^{70}$ Mindful of this, the ECtHR has quickly delivered Opinions in both cases (less than six months in the first and less than ten in the second). This is also noteworthy because in both cases a comparative examination of domestic law and practice (following the European consensus method) took place. ${ }^{71}$ Thus, it has rightly been noted that the 'signal' to the 'domestic court seems to be: yes, using this procedure will halt your domestic case, but this pause will be kept as short as possible'. ${ }^{72}$

In addition, both Opinions were unanimous. Of course, dissenting Opinions in the case law of the Court can be a valuable source for analysis and reflection on the interpretation of the Convention. Nothing precludes the production of dissenting Opinions in the future - if anything, this is explicitly provided for under Protocol 16, and it may even be argued that the non-binding nature of the Opinion somehow presents a welcoming environment for the exposition of alternative approaches to the interpretation of the Convention by the majority view. However, it cannot be excluded that in the first two Opinions at least, the Strasbourg Court wanted to convey the (unanimous) message that the interpretation provided for does not represent either an indefensible or 'activist' development of its case law.

Some remarks on the structure of the Opinions are also warranted. The Opinions start with an exposition of the procedure upon the receipt of the request, followed by the questions asked. Following this, the background to the domestic proceedings is explained. In both cases, a comparative-law examination was undertaken. 'The Court's Opinion' essentially provides the answers to the submitted questions - to the extent that the Court is able to answer (some, or all of) them. In this sense, the Opinions under Protocol 16 present similarities with those issued under Article 47 ECHR - a faculty that has been used infrequently, ${ }^{73}$ serves an entirely different

\footnotetext{
${ }^{69}$ Dzehtsiarou and O’Meara (n 19) 466.

${ }^{70}$ This particular requirement under Article 6 consistently ranks among the highest percentage of violations under the Convention. The ECtHR in its jurisprudence has acknowledged as much: see, for example, the landmark judgment Kudta v Poland [GC] 30210/96 (ECtHR, 26 October 2000), in particular para 148: 'the time has come to review its case-law in the light of the continuing accumulation of applications before it in which the only, or principal, allegation is that of a failure to ensure a hearing within a reasonable time in breach of' Article 6(1).

${ }^{71}$ Buyse (n 38).

72 Ibid.

${ }^{73}$ Only two Opinions have been issued, to date, under Article 47 ECHR - both on legal questions concerning the lists of candidates submitted with a view to the election of judges to the ECtHR; see, $<$ www.echr.coe.int/Pages/home.aspx? $\mathrm{p}=$ caselaw/advisoryopinions\&c=>.
} 
purpose (matters on the content or scope of the rights or freedoms in the ECHR are excluded) and can only be requested by the Committee of Ministers. ${ }^{74}$

\section{Outlook and Concluding Remarks}

Protocol 16 establishes a dialogue between Strasbourg and the national courts. The evidence so far (limited as it inevitably is) suggests that the ECtHR is willing to assist the domestic interlocutors in a rather speedy fashion. Yet, as Gerards has rightly observed, the willingness of national courts (it is remembered that only a list of high-ranking courts are eligible to 'apply') to engage with Protocol 16 will be a key indicator to measure its success. ${ }^{75}$ Time will tell if the national courts will avail themselves of the opportunities arising under Protocol $16 .^{76}$

In this sense, Protocol 16 cannot contribute to an immediate and tangible reduction in the workload of the Court. Its 'educational' value can only have a certain and long-term effect, in this respect. Put differently, its value will be of a qualitative, not quantitative, nature. As observed elsewhere, it is to be hoped that 'further guidance to highest domestic courts could progressively lead to further instances where appropriate redress and/or effective remedies within the domestic legal order would be guaranteed'. ${ }^{77}$ This is not undermined, it is submitted, by the reluctance of the ECtHR to offer abstract guidance to hypothetical questions. In terms of the 'educational' value identified above, some similarity with the pilot-judgment procedure might be discerned as well, despite the obvious differences. ${ }^{78}$

The first two Opinions have also shown that the mechanism will be used to answer novel questions - or at least questions on which there is no settled jurisprudence. Since the Opinions originate from the national courts, the Court of Cassation in France and the Armenian Constitutional Court should be credited with contributing to the clarification, or even the

\footnotetext{
${ }^{74}$ See, also Articles 48 and 49 ECHR. For further discussion see, Dzehtsiarou and O’Meara (n 19) 446-451.

${ }^{75}$ Gerards (n 58) 646-647.

${ }^{76}$ It is noted that at the time of writing (February 2021) two requests for an Advisory Opinion are being examined by the Court: by the Supreme Court of Slovakia on police complaints mechanism and by the Supreme Administrative Court of Lithuania on impeachment legislation; see, $<$ echr.coe.int/Pages/home.aspx? $\mathrm{p}=$ caselaw/advisoryopinions\&c=>. If anything, this shows that the mechanism under Protocol 16 is increasingly being used by eligible courts.

${ }^{77}$ Vogiatzis (n 17) 208.

${ }^{78}$ According to a document produced by the Court, which may also serve as a starting point to underline the differences between the two mechanisms, the objectives of the pilot judgment are: to assist 47 states 'in solving systemic or structural problems at national level'; to 'offer a possibility of speedier redress to the individuals concerned'; and to 'help the European Court of Human Rights manage its workload more efficiently and diligently by reducing the number of similar - usually complex - cases that have to be examined in detail'. See, European Court of Human Rights, 'Pilot Judgments' (2020) available at: $<$ www.echr.coe.int/documents/fs_pilot_judgments_eng.pdf $>$. The first judgment of this type was delivered in the case Broniowski v Poland [GC] 31443/96 (ECtHR, 22 June 2004).
} 
development, of the scope of Articles 8 and 7 ECHR respectively. Although legally the Opinions are non-binding, the views of the Strasbourg Court have now been clarified in two important aspects: regarding Article $8 \mathrm{ECHR}$, 'the Convention requires that domestic law provide a possibility of recognition of a legal parent-child relationship with the intended mother'; 79 and regarding Article 7, the "'blanket reference" or "legislation by reference" technique in criminalising acts or omissions is not in itself incompatible with the requirements of Article 7 of the Convention', while the 'principle of concretisation' may be used to apply the law that is more favourable to the accused in situations where the penalties remain unchanged but the characterisation of the offence has been amended. ${ }^{80}$ The first Opinion has also had an impact on the situation of the applicants in the main proceedings: it has been argued that a 'particularly decisive stage' in their (eventually successful, after 19 years) legal battle was that Opinion. ${ }^{81}$

Lastly, it should be mentioned that not everyone may agree with the accommodating approach towards Protocol 16 (and the Court's practice so far) expressed in this note. Leaving aside those who are generally sceptical of the Convention system, there may be legitimate concerns about whether the Strasbourg Court goes far enough, whether the workload will be reduced, whether dialogue will be genuine, and so on. It is important for the Strasbourg Court to be mindful of any existing or potential criticism and suggestions for improvement. Yet, bearing in mind that this is a novel mechanism, that the number of ratifications is still rather low, and that the responsibility rests with domestic courts as well, this author - for now - assesses positively the contribution of Protocol 16 to the development of the Convention system for human rights protection.

\section{Acknowledgments}

The author would like to thank the anonymous reviewer and the Editorial Board for comments on an earlier version. The usual disclaimer applies.

\footnotetext{
${ }^{79}$ See, operative part of Advisory Opinion P16-2018-001 (n 9).

${ }^{80}$ See, operative part of Advisory Opinion P16-2019-001 (n 10).

${ }^{81}$ Margaria (n 46) 412.
} 